\title{
Communication Satisfaction: A Study on Junior Executives working in Private Sector of Bangladesh
}

\author{
AKHUND A. SHAMSUl ALAM*
}

\begin{abstract}
The study was an attempt to explore the level of communication satisfaction perceived by junior executives working in private sector in Bangladesh. Data were collected using the "Communication Satisfaction Questionnaire" developed by Downs and Hazen's (1977). The Questionnaire consisted of 40 items divided into eight dimensions: Communication Climate, Supervisory Communication, Organizational Integration, Media Quality, Co-worker Communication, Organizational Perspective, Personal Feedback, and Relationship with Subordinates. Data were analyzed with KolmogorovSmirnov, Shapiro-Wilk and Mann-Whitney U tests and by using other suitable statistical tools. The study reported very low level of communication satisfaction perceived by the junior executives. It also found a significant difference in levels of communication satisfaction between male and female executive in terms of "Communication Climate", "Personal Feedback" and "Subordinate Communication”. Finally, recommendations were made for developing and maintaining a better organizational communication to achieve the desired performance and to sustain competition in the long run.
\end{abstract}

Key words: Private Sector, Effective Communication and Communication Satisfaction.

\footnotetext{
* Senior Management Counselor, Bangladesh Institute of Management (BIM), Dhaka E-mail: akhundalam@gmail.com
} 


\section{INTRODUCTION}

Private sector has been playing a significant role in the economic development of Bangladesh. The sector's contribution to growth became more prominent in the 1990s, with steady growth in the production and export of readymade garments, textiles, knitwear, and frozen foods such as shrimp. The sector is driving innovation and growth in many other sectors which have traditionally been dominated by state-owned (government) institutions e.g., Education, Power Generation, Airlines, Healthcare, Television, Infrastructure, etc. According to Bangladesh Bureau of Statistics (BBS), the total investment of GDP in Fiscal Year (FY) 2014-15 was 28.97 percent out of which 22.07 percent was from private sector. Yet even though the sector is growing rapidly, it is still facing a number of significant challenges in order to ensure high productivity through job efficacy, employee satisfaction and organizational commitment. Lack of effective communication in the workplace-downward and upward- is one of the challenges many managers face in this regard.

Organizational Communication, in modern organizations has become far more difficult. It has become an important input for overall organizational functioning and success. The approach an organization takes in communicating with its employees is reflected in morale, motivation and performance of the employees. Good communication within an organization makes it possible to have good human relations. Effective communication is required not only for human relations but for a good and successful organization. In practical terms, there is no organization without communication. Managers use the majority of their time communicating in different forms: face-to-face meeting, discussion, letters, electronic mail.

Analyzing communication effectiveness can play a useful role in determining the organization's communication strategy (Hargie et al., 2002). Different studies have implicated that effective communication is related to job satisfaction (Ehlers, 2003; Goris et al., 2000; Kongchan, 1985; Goldhaber et al., 1978; Marrett et al., 1975), motivation (Chiang, 2003), job performance (Alexander et al., 1989; Pincus, 1986), productivity (Chang, 2006; Clampitt and Downs, 1993; Clampitt, 1983), work values (Raile, 2005), organizational climate (Muchinsky, 1977), leadership styles (Ulloa-Heath, 2003; Oh et al., 1991), organizational identification (Nakra, 2006), and organizational commitment (Nuss, 2006; Varona, 1996; Potvin, 1991). 


\section{RATIONALE OF THE STUDY}

Effective communication is a key element to any organization and can help it in several ways. Communication plays a role in product-based innovations, customer relations, and employee management. It also helps in establishing clear expectations for employees. It also creates expectations among customers. For employees, such expectations will convey how their performance should impact the firm. It gives them an indication of what they require to do to achieve better feedback. For customers, robust communication can help manage their expectations about service issues.

After doing rigorous literature review, it is found that there are many studies which have been done on communication satisfaction in different countries. As the private sector has been the main engine of economic growth and employment generation in Bangladesh, the researcher is inclined to conduct the research in order to know the level of communication satisfaction in this sector which plays the central role in advancing innovation, creating wealth, income and jobs, mobilizing domestic resources and in turn contributing to poverty reduction.

\section{DEFINITIONS OF TERMS}

For the purposes of this study the following terms were defined:

\subsection{Junior Executive}

A junior executive is someone who works under a person or group having administrative or managerial authority in an organization. ${ }^{i}$ The specific details of a junior executive's responsibilities can vary between companies and industries, but the basics remain the same: A junior executive's primary function is to support the executive staff of a company. This position is often seen as a stepping-stone or a "grooming" job on the way to a senior executive position in the company. ${ }^{\text {ii }}$

\subsection{Communication Satisfaction}

Communication satisfaction can be described as an affective feeling, dependent on the level of effectiveness of communication interaction between stakeholders in an organization (Morele 2005:20-21). Thayer (1969) defined the term as "the personal satisfaction a person experiences when communicating successfully". Redding (1978) in an analysis of several studies, reported that communication satisfaction was used to refer to the overall degree of satisfaction an employee perceives in the total communication environment. Downs and Hazen's (1977) research indicates that communication satisfaction is a 
multidimensional construct. These researchers define the term as an individual's satisfaction with various aspects of communication in the organization. ${ }^{\text {iii }}$

\subsection{Contexts and Dimensions of Communication Satisfaction}

The Downs and Hazen model (1977) contains three conceptual contexts of communication satisfaction:

i. Interpersonal communication context;

ii. Group communications context; and

iii. Organizational communication context

Each of these contexts has a set of communication dimensions which influences it (Figure 1). These communication satisfaction dimensions (and their sub-components) were identified by Downs and Adrian (2004) and form the bases of the communication satisfaction theory. In this theoretical framework the eight dimensions are personal feedback; supervisory communication; subordinate communication; horizontal communication; organizational integration; corporate information; communication climate and media quality. 
FIGURE 1

THE DOWNS AND HAZEN COMMUNICATION SATISFACTION FRAMEWORK $^{\text {iv }}$

COMMUNICATION SATISFACTION

\begin{tabular}{|c|}
\hline Interpersonal \\
Communication \\
Context
\end{tabular}

- Personal

Feedback Dimension

$\checkmark$ Job

Performance

$\checkmark$ Recognition

of Efforts

- Supervisory

Communication

Dimension

$\checkmark$ Openness

$\checkmark$ Attention

$\checkmark$ Trust

$\checkmark$ Guidance

- Subordinate

Communication

Dimension

$\checkmark$ Responsiven

ess to Downward

Communication

$\checkmark$ Initiating

Upward

Communication

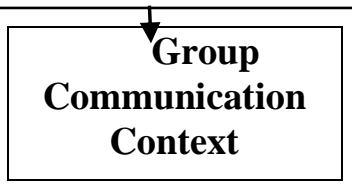

- Horizontal

Communication

Dimension

$\checkmark$ Accuracy of

Coworker

Communication

$\checkmark$ Activeness

of Grapevine

- Organizatio

nal Integration

Dimension

$\checkmark$ Department

al Policies and

Goals

$\checkmark$ Job

Requirements

$\checkmark$ Personnel

News

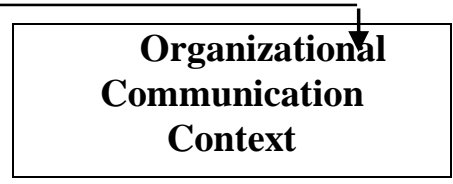

- Corporate

Information Dimension

$\checkmark$ Organizational

Change

$\checkmark$ Profits/Financial

Standing

$\checkmark$ Achievements/Fai

lures

- Communication

Climate Dimension

$\checkmark$ Motivation in the

Organization

$\checkmark$ Identification with

Organization

$\checkmark \quad$ Attitudes toward

Communication

- Media Quality

Dimension

$\checkmark$ Meetings

$\checkmark$ Written Directives

$\checkmark$ Amount of

Information 
A brief definition of each dimension is provided below ${ }^{\mathrm{v}}$ :

i. Corporate Information: Corporate Information deals with the broadest kinds of information about the organization as a whole. It includes items on notification about changes, information about the organizations' financial standing, and information about the overall policies and goals of the organization.

ii. Communication Climate: Communication climate reflects communication on both the organizational and personal level. On one hand, it includes item such as the extent to which communication in the organization motivates and stimulates employees to meet organizational goals and the extent to which it makes them identify with the organization. On the other, it includes estimates of whether or not people's attitudes towards communicating are healthy in the organization.

iii. Media Quality: Media quality deals with the extent to which meetings are well-organized, written directives are short and clear, and the degree to which the amount of communication is about right.

iv. Organizational Integration: Organizational Integration revolves around the degree to which individuals receive information about their immediate work environment. Items include the degree of satisfaction with information about departmental plans, the requirements of their job, and some personnel news.

v. Horizontal Communication: Horizontal communication concerns the extent to which horizontal and informal communication is accurate and free flowing. The factor also includes satisfaction with the activeness of grapevine.

vi. Supervisory Communication: Supervisory Communication includes both upward and downward aspects of communicating with supervisors. Three of the principal items include the extent to which a superior is open to ideas, the extent to which the supervisor listens and pays attention, and the extent to which guidance is offered in solving job-related problems.

vii. Personal Feedback: Personal Feedback is concerned with the workers' need to know how they are being judged and how their performance is being appraised.

viii. Subordinate Communication: Subordinate communication focuses on upward and downward communication with subordinates. Only employees in a supervisory capacity respond to these items which include subordinate responsiveness to downward communication and the extent to which subordinates initiate upward communication 


\section{OBJECTIVES OF THE STUDY}

The objectives of the study are:

i. To identify the extent of communication satisfaction of junior-level executives working in private sector in Bangladesh.

ii. To compare the level of communication satisfaction between male and female junior-level executives working in private sector.

iii. To draw some policy recommendations.

\section{HYPOTHESIS OF THE STUDY}

In light of the objectives of the study, the following null hypotheses have been proposed:

i. $\mathrm{H}_{1}$ : There is no significant correlation among various dimensions of communication satisfaction.

ii. $\quad \mathrm{H}_{2}$ : There is no significant difference in perception between male and female junior level executives towards various dimensions of communication satisfaction.

\section{METHODOLOGY}

This study, cross-sectional in nature, has been carried out to assess the communication satisfaction levels of the junior-level executives' working for different private companies in Dhaka, Narayanganj and Gazipur cities of Bangladesh. The data were collected from August 2015 to September 2015 using a structured questionnaire following Likert's scale. The questionnaire was personally administered to a conveniently selected 396 respondents who took part in the Diploma in Human Resource Management course offered by Bangladesh Institute of Management (BIM), Dhaka. Among them, a total of 284 complete responses ( 72 percent) were received, of which, 216 were male and the others were female. Respondents' mean age is 29.26 years and mean length of service is 3.24 years. Measures of central tendency, dispersion and association (i.e., mean, standard deviation and correlation) have been used as part of descriptive statistics to analyze the data. The Kolmogorov-Smirnov test (K-S test) and Shapiro-Wilk test have been used to determine whether the data are normally distributed in order to choose the appropriate statistical test. Finally, the Mann-Whitney U Test has been used to test the hypotheses. Statistical softwarethe Statistical Package for Social Sciences (SPSS)- has been used to analyze the data. 


\section{MEASUREMENT INSTRUMENT}

The instrument used for this study is the "Communication Satisfaction Questionnaire (CSQ)" developed by Downs and Hazen's (1977). The Questionnaire was constructed to identify individual's degree of communication satisfaction through forty items divided into eight dimensions: Corporate Information, Supervisory Communication, Organizational Integration, Media Quality, Co-worker Communication, Corporate Information, Personal Feedback, and Subordinate Communication. Each satisfaction dimension is measured based on the responses on 5-items per dimension in a 7-point scale ranged between "very dissatisfied" and "very satisfied". The questionnaire has been found internally consistent and reliable across all organizations (Greenbaum et al., 1988). It has proved to be a useful tool for organizational diagnosis in a wide range of organizations.

\section{DATA ANALYSIS}

\subsection{Measures of Central Tendency and Dispersion}

Research objective as to explore the communication satisfaction of juniorlevel executives working in private sector is addressed by examining the mean score of overall and of different dimensions of communication satisfaction. The results are presented below in Table 1.

TABLE 1

COMMUNICATION SATISFACTION PERCEIVED BY JUNIOR EXECUTIVES

\begin{tabular}{|l|c|c|}
\hline \multirow{2}{*}{ Communication Dimensions } & \multicolumn{2}{|c|}{ Perceived Communication Satisfaction } \\
\cline { 2 - 3 } & $\begin{array}{c}\text { Mean Score } \\
\text { (out of 7-point scale) }\end{array}$ & $\begin{array}{c}\text { Std. } \\
\text { Deviation }\end{array}$ \\
\hline Corporate Information & 4.79 & 0.42 \\
\hline Communication Climate & 4.72 & 0.36 \\
\hline Media Quality & 4.80 & 0.37 \\
\hline Organizational Integration & 4.90 & 0.42 \\
\hline Horizontal Communication & 4.76 & 0.42 \\
\hline Supervisory Communication & 4.75 & 0.39 \\
\hline Personal Feedback & 4.50 & 0.23 \\
\hline Subordinate Communication & 4.51 & 0.23 \\
\hline Overall Communication Satisfaction & 4.71 & 0.24 \\
\hline
\end{tabular}

From the Table 1, it can be seen that the level of "overall communication satisfaction" is significantly less since the mean score $(M=4.71)$ fits in below the label of "somewhat satisfied" (value 5 on a 7-point scale). The result also shows that the highest mean score with 'organizational integration' $(M=4.90)$ is found to be very close to the label of "somewhat satisfied" followed by "media quality" $(\mathrm{M}=4.80)$, "Corporate Information" $(\mathrm{M}=4.79)$, "horizontal communication" 
$(\mathrm{M}=4.76)$, "supervisor communication" $(\mathrm{M}=4.75)$ and "communication climate" $(\mathrm{M}=4.71)$. On the contrary, the lowest mean score is found with "personal feedback' $(M=4.50)$ lies exactly between the label of "indifferent" and "somewhat satisfied" followed by "relationship with subordinates" $(\mathrm{M}=4.51)$.

Let us consider the level of satisfaction with forty items under eight dimensions of communication satisfaction. The findings are given below:

\section{Corporate Information}

Level of satisfaction among the respondents with five items under the dimension of "corporate information" is summarized below:

Slightly over one-sixth of the respondents $(15.5 \%)$ are found to be "satisfied" with the information about organizational policies and goals. This could be an indication that these policies and goals are too complex in nature, or are not properly explained to employees. Further, slightly less than three in every ten respondents $(29.2 \%)$ feel "satisfied" with the information about government regulatory action affecting their organizations. This is an area of concern as all organizations operate within a framework of statutory regulations. In addition, almost the same percent of respondents (29.8\%) mark "satisfied" with the information about changes in their organizations. It's the clear indication that the management feels reluctant to communicate organizational changes, may be with organizational structure, process or HR requirements, and if it is done in any way it does not spell out what is expected of them. Besides, about half of the respondents $(48.9 \%)$ are "indifferent" to the information about the organization's financial standing. This indicates that most of the employees don't have free access to financial information of the organizations. Moreover, the lowest percent of the respondents (13.7\%) are "satisfied' with the information about accomplishments and/or failures of their organizations. This is not a good sign as employees have a right to know how their organizations are performing, and therefore the achievements and failures of the organizations should be communicated to them. 


\section{Communication Climate}

Level of satisfaction among the respondents with five items under the dimension of "communication climate" is summarized below:

Over three in every ten $(31.0 \%)$ respondents are "satisfied" with the extent to which the organization's communication motivates and stimulates an enthusiasm for meeting its goals. However, considerably less than one in every ten $(8.1 \%)$ respondents is "satisfied" with the extent to which they receive in time the information needed to do their job. Exactly the same number $(8.1 \%)$ of respondents expresses their satisfaction with the extent to which the people in their organizations have great ability as communicators. These are very disconcerting findings, because in an organization, the continuity of accurate communication is pivotal and therefore communication skills are imperative. Furthermore, only over one in every ten (13.0\%) respondents is "satisfied" with the extent to which conflicts are handled appropriately through proper communication channels. This is also a shocking result because if conflict is managed well it can establish a work environment that is creative, stimulating and vibrant, but if it is handled incorrectly it will result in further destructive behavior and hostility (Van Staden et al., 2002). However, considerably less than half $(42.6 \%)$ of the respondents are "satisfied" with the extent to which the organization's communication makes them identify with it or feel a vital part of it. This indicates that the management needs to take more initiatives to make their employees identify with the vision, mission, goals and objectives of the organization in order to make them feel part of it.

\section{Media Quality}

Level of satisfaction among the respondents with five items under the dimension of "media quality" is summarized below:

Nearly three in every ten respondents (22.9\%) are "satisfied" with the extent to which the organization's communications are interesting and helpful. Yet again, nearly three in every ten respondents $(28.9 \%)$ expresses their satisfaction with the extent to which their meetings are well organized. Furthermore, only one-sixth $(16.9 \%)$ of the respondents are "satisfied" with the extent to which written directives and reports are clear and concise. However, the highest number of respondents $(41.2 \%)$ is "satisfied" with the extent to which the attitudes toward communication in the organization are basically healthy. In contrast, the lowest number of respondents $(13.0 \%)$ is satisfied with the extent to which the amount of communication in the organization is about right. All these clearly 
show that there is huge room for improvement to make the communication effective, interesting and helpful.

\section{Organizational Integration}

Level of satisfaction among the respondents with five items under the dimension of "organizational integration" is summarized below:

Majority of the respondents $(52.1 \%)$ are found to be "satisfied" with the information they receive about their progress in their job. However, only over two in every ten respondents $(21.5 \%)$ are satisfied with the news regarding personnel. It might indicate that their organizations do not have a newsletter that could highlight positive incidents in the organizations to motivate employees and boost morale. Furthermore, just about one-forth (24.6\%) of the respondents are "satisfied" with the information about departmental policies and goals. It might, in turn, make them unsuccessful in meeting the department's goals and fulfilling their professional aspirations. Yet again, slightly over one-forth (26.4\%) of the respondents are "satisfied" with the information about benefits and pay. It's very frustrating as in any employment relationship, sustaining leadership and managing performance will become difficult if employees do not perceive their compensation as fair and equitable (Jooste, 2009). Besides, merely the lowest number $(17.6 \%)$ of the respondents is "satisfied" with the information about the requirements of their job. This is also very upsetting because, job requirements have to be communicated to each employee as early as possible to eliminate the chances of mistakes to the maximum (Jooste, 2009).

\section{Horizontal Communication}

Level of satisfaction among the respondents with five items under the dimension of "horizontal communication" is summarized below:

The lowest number $(15.8 \%)$ of the respondents is "satisfied" with the extent to which the grapevine is active in our organization. Almost the same number $(16.5 \%)$ of respondents is "satisfied" with the extent to which horizontal communication with other organizational members is accurate and free flowing. Furthermore, only three in every ten $(28.2 \%)$ respondents are "satisfied" with the extent to which communication practices are adaptable to emergencies. In addition, over two in every ten (20.8\%) respondents are "satisfied" with the extent to which their work group is compatible. Yet again, nearly three in every ten $(26.4 \%)$ respondents are "satisfied" with the extent to which informal communication is active and accurate. All these findings point out that even 
though informal communication networks exist in the organizations, they cannot be consciously restructured or amended to satisfy the needs of all. This could happen due to lack of accurate and free flow of collegial communication in the organizations.

\section{Supervisory Communication}

Level of satisfaction among the respondents with five items under the dimension of "supervisory communication" is summarized below:

Just one in every ten (10.2\%) respondents is "satisfied" to the extent to which their supervisor listens and pays attention to them. Likewise, slightly over one in every ten (13.4\%) respondents is "satisfied" to the extent to which their supervisor trusts them. In addition, over one-fourth $(26.4 \%)$ of the respondents are "satisfied" with the extent to which their supervisor offers guidance for solving job related problems. Furthermore, nearly one-fifth (19\%) of the respondents are "satisfied" with the extent to which the amount of supervision given them is about right. However, over three-in every ten $(31.3 \%)$ respondents are "satisfied" with the extent to which their supervisor is open to ideas. All these could indicate a breakdown in communication with superiors. These could happen due to lack of trust between managers and employees or insufficient openness exists in the organization.

\section{Personal Feedback}

Unfortunately, not a single respondent is found "satisfied" with all the items under the dimension of "personal feedback". As said by the study, about threefifth $(56.0 \%)$ of the respondents feels "somewhat satisfied" with the information they receive about their performance compared with their peers. More likely it is due to the prejudice of the managers. As stated by Booyens (1998): "Managers are often reluctant to provide feedback to employees with regard to their work performance because the manager is afraid that positive feedback might prompt the employee to demand an increase in salary or a promotion, while negative feedback might elicit arguments." In addition, nearly four in every ten (39.1\%) respondents convey the same degree of satisfaction with the amount and quality of information they get about their performance management. It indicates that the aspirations of employees have not been taken into sufficient consideration, and even they may not know exactly what the supervisor expects of them. Further, over one-fourth $(25.7 \%)$ of the respondents feel "indifferent" as to recognition. It's evident that employees seldom get the recognition they deserve for their efforts. Moreover, about three-fourth $(71.5 \%)$ of the respondents are "indifferent" 
with the amount and or quality of reports on how their job-related problems are handled. Likewise, majority of the respondents (52.8\%) feel "somewhat satisfied" with extent to which their superiors know and understand the problems faced by them. These indicate that management hardly takes note of the employees' problems or considers them important enough to provide sufficient feedback at regular intervals.

\section{Subordinate Communication}

Like 'personal feedback', not a single respondent feels "satisfied" with all the items under the dimension of "subordinate communication". However, about three-fourth $(56.3 \%)$ of the respondents feel "somewhat satisfied" with the extent to which their subordinates are responsive to downward-directed communication. Likewise, over four in every ten (40.1\%) respondents feel the same level of satisfaction to the extent to which their subordinates anticipate their needs for information. On the other hand, over seven in every ten $(70.4 \%)$ respondents are "indifferent" to the extent to which their subordinates are receptive to evaluation, suggestions, and criticisms. All these explain that downward communications are not dealt with in an efficient and timely manner. Furthermore, over half (52.2\%) of the respondents feel "somewhat satisfied" to the extent to which their subordinates feel responsible for initiating accurate upward communication. It shows the lack of the encouragement of upward communication. Last of all, the highest number of respondents (76.8\%) - nearly eight in every ten - are "somewhat satisfied" to the extent to which they do not have a communication overload. It indicates that the rate of information flow, to a great extent, is not within the employees' ability to filter or make sense of it. 


\subsection{Measures of Association}

Hypothesis-1 is addressed by examining the correlations among eight dimensions outlined in Communication Satisfaction Questionnaire. The correlation coefficients are given below in Table 2 .

TABLE 2

CORRELATIONS AMONG VARIOUS DIMENSIONS OF COMMUNICATION SATISFACTION

\begin{tabular}{|c|c|c|c|c|c|c|c|c|}
\hline $\begin{array}{l}\text { Communication } \\
\text { Dimensions }\end{array}$ & (CI) & (SC) & (OI) & (MQ) & (HC) & (OP) & (PF) & (SC) \\
\hline $\begin{array}{l}\text { Corporate } \\
\text { Information }(\mathrm{CI})\end{array}$ & 1 & & & & & & & \\
\hline $\begin{array}{l}\text { Supervisory } \\
\text { Communication (SC) }\end{array}$ & $.304^{* *}$ & 1 & & & & & & \\
\hline $\begin{array}{l}\text { Organizational } \\
\text { Integration (OI) }\end{array}$ & $.504^{* *}$ & $.488^{* *}$ & 1 & & & & & \\
\hline Media Quality (MQ) & $.199^{* *}$ & $.456^{* *}$ & $.487^{* * *}$ & 1 & & & & \\
\hline $\begin{array}{l}\text { Horizontal } \\
\text { Communication (HC) }\end{array}$ & $.526^{* *}$ & $.476^{* *}$ & $.472^{* *}$ & $.312^{* *}$ & 1 & & & \\
\hline $\begin{array}{l}\text { Corporate } \\
\text { Information (OP) }\end{array}$ & $.162^{* * *}$ & $.369^{* *}$ & $.335^{* *}$ & $.267^{* *}$ & $.219^{* *}$ & 1 & & \\
\hline $\begin{array}{l}\text { Personal Feedback } \\
\text { (PF) }\end{array}$ & $.853^{* *}$ & $.219^{* *}$ & $.353^{* *}$ & .115 & $.375^{* *}$ & .057 & 1 & \\
\hline $\begin{array}{l}\text { Subordinate } \\
\text { Communication (SC) }\end{array}$ & $.894^{* *}$ & $.207^{* *}$ & $.399^{* *}$ & $.136^{*}$ & $.417^{* *}$ & .082 & $\begin{array}{l}95 \\
3^{* *}\end{array}$ & 1 \\
\hline
\end{tabular}

**Correlation is significant at the 0.01 level (2-tailed).

*Correlation is significant at the 0.05 level (2-tailed).

The Table 2 shows that there are statistically significant correlations between various dimensions of communication satisfaction.

\subsection{Test of Hypothesis}

In order to test the hypotheses, it is required to apply Student's t-Test which has an underlying assumption that the sample is drawn from normally distributed population (Bajpai, 2005). To test this assumption, the Kolmogorov-Smirnov test (K-S test) and Shapiro-Wilk test have been used. The test statistics are shown below in Table 3. 
TABLE 3

TESTS OF NORMALITY

\begin{tabular}{|l|c|c|c|c|c|c|}
\hline \multirow{2}{*}{$\begin{array}{l}\text { Communication } \\
\text { Dimensions }\end{array}$} & \multicolumn{3}{|c|}{ Kolmogorov-Smirnov $^{\text {a }}$} & \multicolumn{3}{c|}{ Shapiro-Wilk } \\
\cline { 2 - 7 } & Statistic & $\mathbf{d f}$ & Sig. & Statistic & df & Sig. \\
\hline $\begin{array}{l}\text { Corporate } \\
\text { Information }\end{array}$ & .115 & 284 & .000 & .969 & 284 & .000 \\
\hline $\begin{array}{l}\text { Communication } \\
\text { Climate }\end{array}$ & .116 & 284 & .000 & .968 & 284 & .000 \\
\hline Media Quality & .132 & 284 & .000 & .968 & 284 & .000 \\
\hline $\begin{array}{l}\text { Organizational } \\
\text { Integration }\end{array}$ & .125 & 284 & .000 & .968 & 284 & .000 \\
\hline $\begin{array}{l}\text { Horizontal } \\
\text { Communication }\end{array}$ & .135 & 284 & .000 & .963 & 284 & .000 \\
\hline $\begin{array}{l}\text { Supervisory } \\
\text { Communication }\end{array}$ & .131 & 284 & .000 & .966 & 284 & .000 \\
\hline $\begin{array}{l}\text { Personal } \\
\text { Feedback }\end{array}$ & .182 & 284 & .000 & .932 & 284 & .000 \\
\hline $\begin{array}{l}\text { Subordinate } \\
\text { Communication }\end{array}$ & .189 & 284 & .000 & .929 & 284 & .000 \\
\hline
\end{tabular}

a. Lilliefors Significance Correction

The above Table presents the results from two well-known tests of normality, namely the Kolmogorov-Smirnov Test and the Shapiro-Wilk Test. The ShapiroWilk Test is more appropriate for small sample sizes ( $<50$ samples), but can also handle sample sizes as large as $2000{ }^{\mathrm{vi}}$ In this study, since we have only 276 elements, both tests can be used. As the p-value is 0.000 in all cases, we can reject the null hypothesis $\left(\mathrm{H}_{0}\right.$ : sample data is normally distributed) at 5 percent level of significance. Therefore, it can be concluded that the data has not been drawn from normally distributed population. So non-parametric test- 'MannWhitney-U' has been applied to test whether there is a statistically significant difference in perceptions between male and female junior executives towards the dimensions of communication satisfaction individually and in total. Test results have been depicted in Table 4. 
TABLE 4

SUMMARY OF MANN-WHITNEY U TEST

\begin{tabular}{|c|c|c|c|c|c|}
\hline \multirow{2}{*}{$\begin{array}{l}\text { Communication } \\
\text { Dimensions }\end{array}$} & \multicolumn{2}{|c|}{ Mean Rank } & \multirow{2}{*}{$\begin{array}{c}\text { Mann- } \\
\text { Whitney U }\end{array}$} & \multirow[b]{2}{*}{$\mathrm{Z}$ value } & \multirow{2}{*}{$\begin{array}{l}\text { p-value } \\
\text { (2-tailed }\end{array}$} \\
\hline & $\begin{array}{c}\text { Male } \\
(n=216)\end{array}$ & $\begin{array}{c}\text { Female } \\
(\mathrm{n}=68)\end{array}$ & & & \\
\hline Corporate Information & 145.29 & 133.64 & 6741.5 & -1.031 & 0.302 \\
\hline $\begin{array}{l}\text { Communication } \\
\text { Climate }\end{array}$ & 148.92 & 122.11 & 5957.5 & -2.379 & 0.017 \\
\hline Media Quality & 141.95 & 144.26 & 7224.5 & -0.205 & 0.837 \\
\hline $\begin{array}{l}\text { Organizational } \\
\text { Integration }\end{array}$ & 142.44 & 142.70 & 7330.5 & -0.023 & 0.982 \\
\hline $\begin{array}{l}\text { Horizontal } \\
\text { Communication }\end{array}$ & 144.90 & 134.89 & 6826.5 & -0.886 & 0.376 \\
\hline $\begin{array}{l}\text { Supervisory } \\
\text { Communication }\end{array}$ & 143.37 & 139.74 & 7156.5 & -0.321 & 0.748 \\
\hline Personal Feedback & 148.50 & 123.46 & 6049 & -2.27 & 0.023 \\
\hline $\begin{array}{l}\text { Subordinate } \\
\text { Communication }\end{array}$ & 149.16 & 121.35 & 5905.5 & -2.522 & 0.012 \\
\hline $\begin{array}{l}\text { Overall } \\
\text { Communication } \\
\text { Satisfaction }\end{array}$ & 145.66 & 132.48 & 6662.5 & -1.155 & 0.248 \\
\hline
\end{tabular}

From the Table 4, it can be said that the differences between the individual mean ranks of male and female executives (junior level) are not statistically significant at five percent level of significance, except the communication dimensions of 'Communication Climate', 'Personal Feedback' and 'Subordinate Communication'. Therefore, the following inferences can be drawn:

i. The difference in perception between male and female executives (junior level) towards "Communication Climate" is statistically significant as the pvalue is 0.017 . Hence, we can conclude that existing communication climate motivates male more than female executives at junior-level to meet organizational goals.

ii. The difference in observation between male and female executives at junior level towards 'Personal Feedback' is also found statistically significant as the p-value is 0.023 . Thus, we can conclude that male executives receive more personal feedback than that of female executives at junior-level.

iii. The level of satisfaction towards the 'Subordinate Communication' differs significantly between male and female executives at junior-level as the p- 
value is 0.017. Therefore, we can conclude that male executives find subordinates more responsive to downward-directed communication than female executives at junior-level.

iv. But if we consider overall communication satisfaction, the study reveals that there is no statistically significant difference in perception between male and female executives at junior-level towards communication satisfaction as the $\mathrm{p}$ value is 0.248 .

\section{RECOMMENDATIONS}

Based on the findings, the following recommendations are made to improve the effectiveness of communication (and ultimately the communication satisfaction of junior executives) in private sector in Bangladesh. The broad findings and the proposed recommendations for addressing the identified limitations within the interpersonal, group and organizational communication contexts are set out below in table format:

TABLE5

RECOMMENDATIONS FOR IMPROVING COMMUNICATION IN THE INTERPERSONAL COMMUNICATION CONTEXT

\begin{tabular}{|l|l|}
\hline Limitation(s) & Recommendations \\
\hline Dimension 1: Personal Feedback: \\
\hline $\begin{array}{l}\text { Lack of information } \\
\text { on } \\
\text { performance } \\
\text { management }\end{array}$ & $\begin{array}{l}\text { Establish challenging and mutually agreed-upon } \\
\text { performance goals in support of organizational } \\
\text { objectives. }\end{array}$ \\
& $\begin{array}{l}\text { Schedule performance management meetings for } \\
\text { junior executives in the year. }\end{array}$ \\
& $\begin{array}{l}\text { The performance appraisal meeting should be a two- } \\
\text { way conversation in which a manager and employee } \\
\text { review and discuss responsibilities, results, progress } \\
\text { toward objectives and core behaviors. }\end{array}$ \\
\hline Lack of recognition & $\begin{array}{l}\text { Acknowledge junior executives who deliver quality } \\
\text { and excellent work inputs, not only by means of } \\
\text { material rewards but also by means of verbal and or } \\
\text { written recognition. }\end{array}$ \\
& \\
\hline
\end{tabular}


Lack of
understanding of the
job-related problems
faced
by junior executives

- Be more attentive to job-related problems experienced by junior executives, by knowing what issues are at stake in the operational areas.

- Guide junior executives in work-related problem solving by encouragement, directing and mentorship.

\section{Dimension 2: Supervisory Communication:}

Lack of supervisory attention

- Observe, listen and pay attention to what junior executives need and ask for, even if they do through feelings and gestures instead of words.

- Take into consideration the junior executive's view points, background, mind-set, education level, etc. Ensure that the self-respect of the junior executives is maintained and their emotions are not at harm.

- Avoid defensiveness, excuse-making, and answers that are given too quickly. Act with thoughtfulness (Heathfield Susan M., 2015).

\section{Dimension 3: Subordinate Communication:}

Lack of upward directed communication by junior executives
- Avoid downward dominated communication by utilising formal communication structures to allow interactive communication (i.e. meetings or forums).

- Establish regular, expected contact with subordinates by holding daily check-in calls, desk visits or weekly meetings. Greet employees by their proper name and have a cheerful disposition. ${ }^{\text {vii }}$

- Reduce sensitivity of employees to evaluation, suggestions and criticism from managers by providing feedback in a tactful, supportive and oneto-one way focused on developmental needs.

Information overload

- Emphasize on a specific message or goal at a time, rather than trying to achieve too much at once (MSG Experts).

- Provide significant amounts of time for people to ask questions, request clarification, and provide input (Heathfield Susan M., 2015). 
TABLE 6

\section{RECOMMENDATIONS FOR IMPROVING COMMUNICATION IN THE} GROUP COMMUNICATION CONTEXT

\begin{tabular}{|l|l|}
\hline Limitation(s) & Recommendations \\
\hline Dimension 3: Horizontal Communication: \\
\hline $\begin{array}{l}\text { Dysfunctional } \\
\text { informal } \\
\text { communication } \\
\text { channels }\end{array}$ & $\begin{array}{l}\text { Preferably only information with a low priority } \\
\text { should be sent through the grapevine. } \\
\text { Provide employees with accurate information to } \\
\text { avoid distortion of information by hearsay and } \\
\text { gossip. }\end{array}$ \\
\hline Dimension 5: Organizational integration \\
\hline $\begin{array}{l}\text { Lack of information } \\
\text { on job progress }\end{array}$ & $\begin{array}{l}\text { Update junior executives on progress in their jobs } \\
\text { (how well they are developing in their jobs) by } \\
\text { providing them with feedback and guiding career } \\
\text { planning. }\end{array}$ \\
$\begin{array}{l}\text { Provide opportunities for employees to network with } \\
\text { each other, both formally and informally, to share } \\
\text { ideas about change and change management } \\
\text { (Heathfield Susan M., 2015). }\end{array}$ \\
\hline $\begin{array}{l}\text { Incomprehensible } \\
\text { policies }\end{array}$ & $\begin{array}{l}\text { Policies should be written in a simple, clear and } \\
\text { concise format enabling easy comprehension. } \\
\text { All new and key concepts should be defined and } \\
\text { explained, and a list of abbreviations should be } \\
\text { included. }\end{array}$ \\
\hline
\end{tabular}


TABLE 7

RECOMMENDATIONS FOR IMPROVING COMMUNICATION IN THE ORGANIZATIONAL COMMUNICATION CONTEXT

\begin{tabular}{|c|c|}
\hline Limitation(s) & Recommendations \\
\hline \multicolumn{2}{|c|}{ Dimension 6: Corporate information } \\
\hline $\begin{array}{l}\text { Lack of information } \\
\text { about change, } \\
\text { financial standing, } \\
\text { and achievements of } \\
\text { the organization }\end{array}$ & $\begin{array}{l}\text { - Implement a corporate communication channel } \\
\text { which informs all employees via the electronic media } \\
\text { about impending change, profits, financial standing } \\
\text { and achievements or failures of the organization. } \\
\text { - Start a newsletter highlighting events in the } \\
\text { organization. }\end{array}$ \\
\hline \multicolumn{2}{|c|}{ Dimension 7: Communication climate: } \\
\hline $\begin{array}{l}\text { Lack of motivation } \\
\text { and organizational } \\
\text { identification }\end{array}$ & $\begin{array}{l}\text { - Organizational identification should be evident in the } \\
\text { conduct, behaviour and identification of managers at } \\
\text { all levels. } \\
\text { - Involve employees in activities to improve the } \\
\text { organization's professional image. } \\
\text { - Probe employees by means of the SWOT analysis } \\
\text { and surveys on possible improvements. }\end{array}$ \\
\hline $\begin{array}{l}\text { Insufficient } \\
\text { information to do the } \\
\text { job }\end{array}$ & $\begin{array}{l}\text { - Clearly communicate the vision, the mission, and the } \\
\text { objectives of the change management effort. } \\
\text { - Provide employees with updated and relevant } \\
\text { information on issues (i.e. new technologies and } \\
\text { changes in protocols) that could affect their jobs. } \\
\text { - Regularly update and make available all policies and } \\
\text { procedures to all employees. }\end{array}$ \\
\hline $\begin{array}{l}\text { Lack of proper } \\
\text { channels of } \\
\text { communication to } \\
\text { handle conflicts } \\
\text { appropriately }\end{array}$ & $\begin{array}{l}\text { - Adopt an open-door policy in order to be } \\
\text { approachable in addressing issues in the workplace. } \\
\text { - Educate junior executives on the effective prevention } \\
\text { and handling of conflict. } \\
\text { - Schedule conflict management training sessions for } \\
\text { junior executives to equip them to handle the day-to- } \\
\text { day conflict situations in the organizations. }\end{array}$ \\
\hline
\end{tabular}




\begin{tabular}{|l|l|}
\hline \multicolumn{2}{|l|}{ Dimension 8: Media Quality: } \\
\hline $\begin{array}{l}\text { Inappropriate/ } \begin{array}{l}\text { inadequate formats } \\
\text { of communication }\end{array} \\
\text { - }\end{array}$ & $\begin{array}{l}\text { Distribute important information in formal written } \\
\text { format (i.e. memorandums, policy statements, } \\
\text { procedures). }\end{array}$ \\
& $\begin{array}{l}\text { Follow up verbal messages with written messages for } \\
\text { verification. }\end{array}$ \\
\hline $\begin{array}{l}\text { Distribute messages through electronic media (i.e. } \\
\text { via e-mail or as text messages) as well. }\end{array}$ \\
$\begin{array}{l}\text { Poor attitude toward } \\
\text { the organization in }\end{array}$ & $\begin{array}{l}\text { Encourage the employees to treat one another with } \\
\text { courtesy, caring and consideration during all forms of } \\
\text { communication in the organization. } \\
\text { The sender of the message must take into } \\
\text { consideration the receiver's mind set and convey the } \\
\text { message accordingly (MSG Experts, 2015). }\end{array}$ \\
\hline
\end{tabular}

\section{CONCLUSIONS}

Employee communication satisfaction is important because it plays a central role for organizational effectiveness. When communication is effective, it tends to encourage better performance and job satisfaction. People understand their jobs better and feel more involved in them (Chand Smriti). Contrary, if organizational communication is inadequate, it results low organizational commitment, more absenteeism, greater employee turnover, and less productivity (Hargie et al., 2002).

Furthermore, communication serves as the foundation of every facet of a business. It acts as a source of information and helps in the decision making process and helps in identifying the alternative course of action. It also helps in building people's attitude. A well informed person will always have better attitude than a less informed person (EduKart, 2013).

${ }^{\mathrm{i}}$ Answered by The WikiAnswers ${ }^{\circledR}$ Community; Available at: http://www.answers.com/Q/What_is_the_Description_of_a_junior_executive_for _a_company 
${ }^{i i}$ Keith Harlow (n.d), Job Description of a Junior Executive, n.p., Available at: http://www.ehow.com/facts_6826076_job-description-junior-executive.html

iii Varona Federico (2002), Conceptualization and Management of Communication Satisfaction and Organizational Commitment in Three Guatemalan Organizations, American Communication Journal, Volume 5, Issue 3; Available at: http://www.ac-journal.org/

${ }^{\text {iv }}$ Downs and Adrians (2004) from the Downs and Hazen (1977) Model

v Phillip G. Clampitt and Cal W. Downs (1993), Employee Perceptions of the Relationship Between Communication and Productivity: A Field Study, International Journal of Business Communication, Volume 30, No. 1, pp. 5-28.

${ }^{v i}$ Laerd Statistics (2013), Testing for Normality using SPSS Statistics, Available at: https://statistics.laerd.com/spss-tutorials/testing-for-normality-using-spssstatistics.php

vii Patrick Monica (n.d.), How to Build Relationships with Subordinates at Work, Demand Media; Available at: http://smallbusiness.chron.com/build-relationshipssubordinates-work-25015.html 